\title{
Pengaruh Kompetensi, Kompensasi terhadap Kinerja melalui Motivasi Karyawan SIMPro PT. Solusi Inti Multiteknik
}

\author{
Indah Mardiana \\ Universitas Jayabaya Jakarta \\ Indahmardiana1808@gmail.com
}

\author{
Kasmir \\ Universitas Jayabaya Jakarta \\ kasmirpos@yahoo.com ${ }^{2}$
}

\section{Safuan $^{3}$}

Pasca Sarjana Universitas Jayabaya Jakarta safuan@jayabaya.ac.id

\begin{abstract}
Abstrak Penelitian ini bertujuan untuk menganalisis dan menguji pengaruh kompetensi (X1), kompensasi (X2) dan motivasi (X3) terhadap kinerja (Y) karyawan. Hipotesis yang diuji adalah: (1) terdapat pengaruh kompetensi terhadap kinerja; (2) terdapat pengaruh kompensasi terhadap kinerja; (3) terdapat pengaruh motivasi terhadap kinerja; (4) terdapat pengaruh kompetensi terhadap motivasi; dan (5) terdapat pengaruh kompensasi terhadap motivasi. Penelitian ini menggunakan metode penelitian asosiatif kuantitatif survei dengan menggunakan teknik analisis jalur. Populasi dalam penelitian ini adalah seluruh karyawan PT. Solusi Inti Multiteknik. Dengan sampel sebanyak 105 karyawan. Penelitian ini dilaksanakan pada PT. Solusi Inti Multiteknik. Hasil penelitian menunjukkan bahwa pengaruh kompetensi terhadap kinerja melalui motivasi memiliki kontribusi yang paling kuat sebesar 45,10\%,sedangkan 54.90\%lainnya ditentukan oleh faktor-faktor lain yang tidak termasuk dalam penelitian ini. Implikasi penelitian ini menunjukkan bahwa kompetensi yang baik, kompensasi dan motivasi yang tinggi akan meningkatkan kinerja para karyawan.Kinerja diasumsikan dipengaruhi secara positif oleh kompetensi, kompensasi dan motivasi yang berkaitan di PT. Solusi Inti Multiteknik. Kesimpulan penelitian ini membuktikan bahwa kompetensi, kompensasi dan motivasi mempengaruhi Kinerja Karyawan.
\end{abstract}

Kata Kunci Kinerja, Kompetensi, Kompensasi, Motivasi

\section{PENDAHULUAN}

Pada era global saat ini, perusahaan dihadapkan pada kondisi persaingan yang semakin meningkat sehingga dituntut harus lebih kreatif dan inovatif dalam menawarkan sesuatu yang bernilai tambah dibandingkan yang dilakukan pesaing. Perusahaan sebagai salah satu lembaga 
perekonomian dituntut secara aktif didalam pelaksanaan pembangunan. Melalui aktivitas ekonomi, perusahaan dapat memberikan pelayanan dan memenuhi kebutuhan masyarakat yang beraneka ragam, baik kebutuhan jasa maupun kebutuhan akan produk barang dan jasa.

PT. Solusi Inti Multiteknik merupakan salah satu perusahaan yang bergerak dalam bidang jasa dan penjualan yang mempunyai 3 cabang di kota besar. Produk-produk yang ditawarkan ke customer mencangkup kebutuhan customer. Dengan 3 pillar bisnis yaitu : SIM Care, SIM Pro dan SIM Store customer bisa melakukan pembelian ponsel, perbaikan dan juga proteksi ponsel kesayangan mereka.

Sumber daya manusia adalah faktor pendukung bagi perusahaan untuk bertahan dalam persaingan. Kompetensi dan kompensasi memainkan peran penting dalam meningkatkan motivasi dan kinerja karyawan, salah satu alasan utama seseorang bekerja adalah untuk memenuhi kebutuhan hidup. Seseorang akan bekerja secara maksimal untuk mendapatkan kompensasi sesuai dengan harapan. kompensasi selain menghargai karyawan untuk pekerjaan yang dilakukan oleh karyawan juga merupakan salah satu cara untuk mempertahankan karyawan potensial.

Kompetensi penting untuk meningkatkan daya saing bagi masing-masing karyawan agar bisa terus berinovasi dan berkreasi serta menjadi acuan untuk bersaing secara sehat sesama karyawan. Kompetensi penting dilakukan demi mengetahui karyawan yang potensial di suatu perusahaan, agar tujuan perusahaan bisa tercapai karena karyawan yang memiliki kemampuan dan sejalan dengan visi dan misinya. Setelah kompetensi dilakukan perlu diberikannya kompensasi, jika kompensasi tidak diberikan dengan adil besar kemungkinan bisa menjadikan karyawan meninggalkan perusahaan yang akan mengakibatkan kerugian besar bagi perusahaan. Semakin besar kompensasi yang diberikan akan berpengaruh terhadap kinerja karyawan itu sendiri, dan menguntungkan bagi perusahaan.

Melalui penelitian ini, peneliti ingin mengetahui dan menganalisis apakah kompetensi dan kompensasi yang diberikan sudah sesuai atau tidak, kompetensi yang sudah dilakukan apakah sesuai dengan keinginan perusahaan untuk mencapai hasil yang diinginkan dari karyawan, dari kompensasi dan juga kompetensi apakah bisa meningkatkan motivasi yang akan berdampak pada kinerja karyawan.

\section{METODE PENELITIAN}

Pada penelitian ini jenis penelitian yang akan digunakan adalah explanatory research atau penelitian penjelasan. explanatory research adalah suatu penelitian dimana peneliti menjelaskan hubungan kausal sebab akibat antara variabel-variabel melalui pengujian hipotesa. Penelitian ini menggunakan jenis penelitian explanatory research karena hendak menjelaskan hubungan kausal yang terjadi antara kompensasi dan kompetensi terhadap motivasi dan dampaknya untuk kinerja karyawan yang telah dijelaskan dalam bab sebelumnya.

Metode yang dilakukan dalam penelitian ini adalah metode survei yang merupakan metode dengan mengambil sampel dari suatu populasi dan menggunakan kuisioner sebagai alat pengumpulan data. Setelah data diperoleh kemudian hasilnya akan dipaparkan secara desktiptif dan pada akhir penelitian ini akan dianalisis untuk menguji hipotesis yang diajukan pada awal penelitian.

\section{HASIL DAN PEMBAHASAN}


Deskripsi data yang disajikan dalam bagian ini meliputi data variabel-variabel kompetensi $\left(\mathrm{X}_{1}\right)$, kompensasi $\left(\mathrm{X}_{2}\right)$, motivasi $\left(\mathrm{X}_{3}\right)$ dan kinerja $(\mathrm{Y})$. Seperti telah diuraikan dalam bab sebelumnya, penelitian ini mengkaji pengaruh antara variabel-variabel yang diteliti, dimana jenis variabel yang digunakan adalah variabel terikat dan variabel bebas. Dalam penelitian ini variabel terikat adalah kinerja $(\mathrm{Y})$ sedangkan variabel bebas adalah kompetensi $\left(\mathrm{X}_{1}\right)$, kompensasi $\left(\mathrm{X}_{2}\right)$ dan motivasi $\left(\mathrm{X}_{3}\right)$.

\section{Uji Validitas}

Hasil uji validitas dilakukan dengan menggunakan korelasi Product Moment (Person). Dalam uji validitas ini, kriteria suatu nilai dikatakan valid jika $r$ hitung lebih besar dari $r$ tabel, adapun untuk mengetahui nilai $r$-hitung pada tabel statistik dengan $\mathrm{n}=105$; degree of freedom (df) $=\mathrm{n}-2 ; \alpha=0,05$ dengan demikian diperoleh nilai $\mathrm{r}$ tabel $=0,192$. Untuk menguji validitas dalam penelitian ini dilakukan dengan bantuan software SPSS versi 20.

Menurut Ghozali (2016:45) nilai r hitung ditunjukkan oleh nilai Corrected Item-Total Correlation pada output SPSS. Dengan demikian jika suatu pertanyaan memiliki nilai Corrected Item-Total Correlation ( $\mathrm{r}$ hitung) $\geq$ dari 0,192 berarti butir pertanyaan tersebut dinyatakan valid.

Tabel 1. Hasil Uji Validitas Kompetensi

Item-Total Statistics

\begin{tabular}{|l|r|r|r|r|r|}
\hline & $\begin{array}{c}\text { Scale Mean if } \\
\text { Item Deleted }\end{array}$ & $\begin{array}{c}\text { Scale } \\
\text { Variance if } \\
\text { Item Deleted }\end{array}$ & $\begin{array}{c}\text { Corrected } \\
\text { Item-Total } \\
\text { Correlation }\end{array}$ & $\begin{array}{c}\text { Squared } \\
\text { Multiple } \\
\text { Correlation }\end{array}$ & $\begin{array}{c}\text { Cronbach's } \\
\text { Alpha if Item } \\
\text { Deleted }\end{array}$ \\
\hline P1 & 38.6000 & 13.781 & .634 & .583 & .786 \\
P2 & 38.7429 & 13.654 & .607 & .611 & .787 \\
P3 & 38.6095 & 13.683 & .663 & .605 & .784 \\
P4 & 38.6667 & 12.801 & .647 & .733 & .780 \\
P5 & 38.8857 & 12.314 & .713 & .800 & .771 \\
P6 & 38.6286 & 12.813 & .620 & .545 & .783 \\
P7 & 38.5714 & 13.978 & .536 & .594 & .795 \\
P8 & 38.6952 & 15.175 & .176 & .230 & .836 \\
P9 & 38.5810 & 15.303 & .226 & .843 & .825 \\
P10 & 38.5905 & 15.340 & .229 & .848 & .824 \\
\hline
\end{tabular}

\begin{tabular}{|l|c|c|c|}
\hline \multicolumn{4}{|c|}{ Validitas Butir-Butir Pertanyaan Kuesioner } \\
\hline Item & R $_{\text {Hitung }}$ & $\mathbf{R}_{\text {Tabel }}$ & Validitas \\
\hline Pertanyaan 1 & 0,634 & 0,192 & Valid \\
\hline Pertanyaan 2 & 0,607 & 0,192 & Valid \\
\hline Pertanyaan 3 & 0,663 & 0,192 & Valid \\
\hline Pertanyaan 4 & 0,647 & 0,192 & Valid \\
\hline Pertanyaan 5 & 0,713 & 0,192 & Valid \\
\hline Pertanyaan 6 & 0,620 & 0,192 & Valid \\
\hline Pertanyaan 7 & 0,536 & 0,192 & Valid \\
\hline Pertanyaan 8 & 0,176 & 0,192 & Tidak Valid \\
\hline
\end{tabular}




\begin{tabular}{|l|c|c|c|}
\hline Pertanyaan 9 & 0,226 & 0,192 & Valid \\
\hline Pertanyaan 10 & 0,229 & 0,192 & Valid \\
\hline
\end{tabular}

Berdasarkan hasil uji validitas data pada variabel kompetensi (X1) perbandingan antara $r$ tabel dan $r$ hitung untuk mengukur tingkat validitas data pada 10 item pertanyaan. Terlihat bahwa dari 10 item pertanyaan variabel kompetensi (X1) hanya 9 item pertanyaan variabel kompetensi (X1) yang valid. Hal ini dikarenakan 9 item kuesioner memiliki nilai Corrected Item-Total Correlation ( $\mathrm{r}$ hitung) > 0,192 ( $\mathrm{r}$ tabel). Dan ada 1 item pertanyaan yang tidak valid dikarenakan 1 item kuesioner memiliki nilai Corrected Item-Total Correlation ( $\mathrm{r}$ hitung) < 0,192 ( $\mathrm{r}$ tabel).

Tabel 2. Hasil Uji Validitas Kompensasi

Item-Total Statistics

\begin{tabular}{|l|r|r|r|r|r|}
\hline & $\begin{array}{c}\text { Scale Mean if } \\
\text { Item Deleted }\end{array}$ & $\begin{array}{c}\text { Scale } \\
\text { Variance if } \\
\text { Item Deleted }\end{array}$ & $\begin{array}{c}\text { Corrected } \\
\text { Item-Total } \\
\text { Correlation }\end{array}$ & $\begin{array}{c}\text { Squared } \\
\text { Multiple } \\
\text { Correlation }\end{array}$ & $\begin{array}{c}\text { Cronbach's } \\
\text { Alpha if Item } \\
\text { Deleted }\end{array}$ \\
\hline P1 & 38.6000 & 13.781 & .634 & .583 & .786 \\
P2 & 38.7429 & 13.654 & .607 & .611 & .787 \\
P3 & 38.6095 & 13.683 & .663 & .605 & .784 \\
P4 & 38.6667 & 12.801 & .647 & .733 & .780 \\
P5 & 38.8857 & 12.314 & .713 & .800 & .771 \\
P6 & 38.6286 & 12.813 & .620 & .545 & .783 \\
P7 & 38.5714 & 13.978 & .536 & .594 & .795 \\
P8 & 38.6952 & 15.175 & .176 & .230 & .836 \\
P9 & 38.5810 & 15.303 & .226 & .843 & .825 \\
P10 & 38.5905 & 15.340 & .229 & .848 & .824 \\
\hline
\end{tabular}

\begin{tabular}{|l|c|c|c|}
\hline \multicolumn{4}{|c|}{ Validitas Butir-Butir Pertanyaan Kuesioner } \\
\hline Item & $\begin{array}{c}\text { Corrected item total } \\
\text { correlation (r Hitung) }\end{array}$ & r Tabel & Validitas \\
\hline Pertanyaan 1 & 0,727 & 0,192 & Valid \\
\hline Pertanyaan 2 & 0,751 & 0,192 & Valid \\
\hline Pertanyaan 3 & 0,761 & 0,192 & Valid \\
\hline Pertanyaan 4 & 0,803 & 0,192 & Valid \\
\hline Pertanyaan 5 & 0,843 & 0,192 & Valid \\
\hline Pertanyaan 6 & 0,892 & 0,192 & Valid \\
\hline Pertanyaan 7 & 0,631 & 0,192 & Valid \\
\hline Pertanyaan 8 & 0,694 & 0,192 & Valid \\
\hline Pertanyaan 9 & 0,750 & 0,192 & Valid \\
\hline Pertanyaan 10 & 0,002 & 0,192 & Tidak Valid \\
\hline
\end{tabular}

Berdasarkan hasil uji validitas data pada variabel kompensasi $\left(\mathrm{X}_{2}\right)$ perbandingan antara $\mathrm{r}$ tabel dan $r$ hitung untuk mengukur tingkat validitas data pada 10 item pertanyaan terlihat bahwa dari 10 item pertanyaan variabel kompensasi $\left(\mathrm{X}_{2}\right)$ hanya 9 item pertanyaan variabel kompetensi $\left(\mathrm{X}_{2}\right)$ yang valid. Hal ini dikarenakan 9 item kuesioner memiliki nilai Corrected Item-Total 
Correlation ( $\mathrm{r}$ hitung) $>0,192(\mathrm{r}$ tabel). Dan ada 1 item pertanyaan yang tidak valid dikarenakan 1 item kuesioner memiliki nilai Corrected Item-Total Correlation ( $\mathrm{r}$ hitung) $<0,192$ ( $\mathrm{r}$ tabel).

Tabel 3. Hasil Uji Validitas Motivasi

Item-Total Statistics

\begin{tabular}{|l|r|r|r|r|r|}
\hline & $\begin{array}{c}\text { Scale Mean if } \\
\text { Item Deleted }\end{array}$ & $\begin{array}{c}\text { Scale } \\
\text { Variance if } \\
\text { Item Deleted }\end{array}$ & $\begin{array}{c}\text { Corrected } \\
\text { Item-Total } \\
\text { Correlation }\end{array}$ & $\begin{array}{c}\text { Squared } \\
\text { Multiple } \\
\text { Correlation }\end{array}$ & $\begin{array}{c}\text { Cronbach's } \\
\text { Alpha if Item } \\
\text { Deleted }\end{array}$ \\
\hline P1 & 37.4762 & 21.560 & .609 & .467 & .825 \\
P2 & 37.4000 & 21.281 & .596 & .547 & .825 \\
P3 & 37.4381 & 21.575 & .608 & .541 & .825 \\
P4 & 37.8571 & 20.008 & .744 & .652 & .810 \\
P5 & 37.6952 & 20.214 & .628 & .708 & .822 \\
P6 & 37.8571 & 18.854 & .747 & .803 & .808 \\
P7 & 37.5143 & 21.195 & .628 & .630 & .822 \\
P8 & 37.4952 & 22.175 & .571 & .607 & .829 \\
P9 & 37.3714 & 24.890 & .190 & .334 & .855 \\
P10 & 37.5810 & 25.496 & .051 & .314 & .868 \\
\hline
\end{tabular}

\begin{tabular}{|l|c|c|c|}
\hline \multicolumn{4}{|c|}{ Validitas Butir-Butir Pertanyaan Kuesioner } \\
\hline \multicolumn{1}{|c|}{ Item } & $\begin{array}{c}\text { Corrected item total } \\
\text { correlation (r Hitung) }\end{array}$ & $\mathbf{r}$ Tabel & Validitas \\
\hline Pertanyaan 1 & 0,609 & 0,192 & Valid \\
\hline Pertanyaan 2 & 0,596 & 0,192 & Valid \\
\hline Pertanyaan 3 & 0,608 & 0,192 & Valid \\
\hline Pertanyaan 4 & 0,744 & 0,192 & Valid \\
\hline Pertanyaan 5 & 0,628 & 0,192 & Valid \\
\hline Pertanyaan 6 & 0,747 & 0,192 & Valid \\
\hline Pertanyaan 7 & 0,628 & 0,192 & Valid \\
\hline Pertanyaan 8 & 0,571 & 0,192 & Valid \\
\hline Pertanyaan 9 & 0,190 & 0,192 & Tidak Valid \\
\hline Pertanyaan 10 & 0,051 & 0,192 & Tidak Valid \\
\hline
\end{tabular}

Berdasarkan hasil uji validitas data pada variabel motivasi $\left(\mathrm{X}_{3}\right)$ perbandingan antara $\mathrm{r}$ tabel dan $r$ hitung untuk mengukur tingkat validitas data pada 10 item pertanyaan terlihat bahwa dari 10 item pertanyaan variabel motivasi $\left(\mathrm{X}_{3}\right)$ hanya 8 item pertanyaan variabel motivasi $\left(\mathrm{X}_{3}\right)$ yang valid. Hal ini dikarenakan 8 item kuesioner memiliki nilai Corrected Item-Total Correlation (r hitung) > 0,192 ( $\mathrm{r}$ tabel). Dan ada 2 item pertanyaan yang tidak valid dikarenakan 1 item kuesioner memiliki nilai Corrected Item-Total Correlation ( $\mathrm{r}$ hitung) $<0,192$ ( $\mathrm{r}$ tabel). 
Tabel 4. Hasil Uji Validitas Kinerja

Item-Total Statistics

\begin{tabular}{|l|r|r|r|r|r|}
\hline & $\begin{array}{c}\text { Scale Mean if } \\
\text { Item Deleted }\end{array}$ & $\begin{array}{c}\text { Scale } \\
\text { Variance if } \\
\text { Item Deleted }\end{array}$ & $\begin{array}{c}\text { Corrected } \\
\text { Item-Total } \\
\text { Correlation }\end{array}$ & $\begin{array}{c}\text { Squared } \\
\text { Multiple } \\
\text { Correlation }\end{array}$ & $\begin{array}{c}\text { Cronbach's } \\
\text { Alpha if Item } \\
\text { Deleted }\end{array}$ \\
\hline P1 & 39.8381 & 16.714 & .541 & .494 & .884 \\
P2 & 39.6286 & 15.697 & .684 & .726 & .874 \\
P3 & 39.4952 & 15.695 & .751 & .770 & .869 \\
P4 & 39.6762 & 16.163 & .637 & .495 & .877 \\
P5 & 39.3143 & 17.198 & .583 & .581 & .882 \\
P6 & 39.5524 & 14.596 & .760 & .676 & .868 \\
P7 & 39.4667 & 15.963 & .614 & .643 & .879 \\
P8 & 39.6000 & 17.223 & .473 & .495 & .888 \\
P9 & 39.6286 & 16.120 & .673 & .515 & .875 \\
P10 & 39.8000 & 15.950 & .565 & .455 & .883 \\
\hline
\end{tabular}

\begin{tabular}{|l|c|c|c|}
\hline \multicolumn{4}{|c|}{ Validitas Butir-Butir Pertanyaan Kuesioner } \\
\hline Item & $\begin{array}{c}\text { Corrected item total } \\
\text { correlation (r Hitung) }\end{array}$ & $\mathbf{r}$ Tabel & Validitas \\
\hline Pertanyaan 1 & 0,506 & 0,192 & Valid \\
\hline Pertanyaan 2 & 0,684 & 0,192 & Valid \\
\hline Pertanyaan 3 & 0,751 & 0,192 & Valid \\
\hline Pertanyaan 4 & 0,637 & 0,192 & Valid \\
\hline Pertanyaan 5 & 0,583 & 0,192 & Valid \\
\hline Pertanyaan 6 & 0,760 & 0,192 & Valid \\
\hline Pertanyaan 7 & 0,614 & 0,192 & Valid \\
\hline Pertanyaan 8 & 0,473 & 0,192 & Valid \\
\hline Pertanyaan 9 & 0,673 & 0,192 & Valid \\
\hline Pertanyaan 10 & 0,565 & 0,192 & Valid \\
\hline
\end{tabular}

Berdasarkan hasil uji validitas data pada variabel motivasi $\left(\mathrm{X}_{3}\right)$ perbandingan antara $\mathrm{r}$ tabel dan $r$ hitung untuk mengukur tingkat validitas data pada 10 item pertanyaan terlihat bahwa dari 10 item pertanyaan variabel kinerja $(\mathrm{Y})$ semuanya valid. Hal ini dikarenakan seluruh item kuesioner memiliki nilai Corrected Item-Total Correlation ( $\mathrm{r}$ hitung) > 0,192 ( $\mathrm{r}$ tabel).

\section{Uji Reliabilitas}

Nilai Cronbach's Alpha yang digunakan untuk menguji realibilitas adalah nilai Cronbach's Alpha Based on Standardized Items dari output SPSS. Untuk mempercepat hasil perhitungan maka digunakan program SPSS versi 20. Berikut ini adalah hasil pengujian reliabilitas. 
Tabel 5. Perhitungan Reliabilitas

Reliability Statistics

\begin{tabular}{|c|c|r|}
\hline $\begin{array}{c}\text { Cronbach's } \\
\text { Alpha }\end{array}$ & $\begin{array}{c}\text { Cronbach's } \\
\text { Alpha Based } \\
\text { on } \\
\text { Standardized } \\
\text { Items }\end{array}$ & N of Items \\
\hline .815 & .818 & 10 \\
\hline
\end{tabular}

Reliability Statistics

\begin{tabular}{|c|c|r|}
\hline $\begin{array}{c}\text { Cronbach's } \\
\text { Alpha }\end{array}$ & $\begin{array}{c}\text { Cronbach's } \\
\text { Alpha Based } \\
\text { on } \\
\text { otandardized } \\
\text { Items }\end{array}$ & N of Items \\
\hline .845 & .835 & 10 \\
\hline
\end{tabular}

Reliability Statistics

\begin{tabular}{|c|c|r|}
\hline $\begin{array}{c}\text { Cronbach's } \\
\text { Alpha }\end{array}$ & $\begin{array}{c}\text { Cronbach's } \\
\text { Alpha Based } \\
\text { on } \\
\text { Standardized } \\
\text { Items }\end{array}$ & N of Items \\
\hline .911 & .911 & 10 \\
\hline
\end{tabular}

Reliability Statistics

\begin{tabular}{|c|c|r|}
\hline $\begin{array}{c}\text { Cronbach's } \\
\text { Alpha }\end{array}$ & $\begin{array}{c}\text { Cronbach's } \\
\text { Alpha Based } \\
\text { on } \\
\text { Standardized } \\
\text { Items }\end{array}$ & N of Items \\
\hline .889 & .889 & 10 \\
\hline
\end{tabular}

\begin{tabular}{|l|c|c|c|}
\hline \multicolumn{1}{|c|}{ Variabel } & $\begin{array}{c}\text { Reliabilitas } \\
\text { Coefficient }\end{array}$ & Alpha Cronbach & Keputusan \\
\hline Kompetensi & 0,60 & 0,818 & Reliabel \\
\hline Kompensasi & 0,60 & 0,911 & Reliabel \\
\hline Motivasi & 0,60 & 0,835 & Reliabel \\
\hline Kinerja & 0,60 & 0,889 & Reliabel \\
\hline
\end{tabular}

Berdasarkan tabel diatas dapat diketahui bahwa keseluruhan variabel ternyata memiliki nilai cronbach alpha $\geq 0,60$. Dengan demikian, maka hasil uji reliabilitas terhadap keseluruhan variabel adalah reliabel.

\section{Uji Normalitas}

Tabel 6. Uji Normalitas 
One-Sample Kolmogorov-Smirnov Test

\begin{tabular}{|c|c|c|}
\hline & & Kompensasi \\
\hline$N$ & & 105 \\
\hline \multirow[t]{2}{*}{ Normal Parameters ${ }^{a, b}$} & Mean & 33.7714 \\
\hline & Std. Deviation & 6.41701 \\
\hline \multirow[t]{3}{*}{ Most Extreme Differences } & Absolute & .114 \\
\hline & Positive & .114 \\
\hline & Negative & -.100 \\
\hline Kolmogorov-Smirnov Z & & 1.172 \\
\hline Asymp. Sig. (2-tailed) & & .128 \\
\hline
\end{tabular}

a. Test distribution is Normal.

b. Calculated from data.
One-Sample Kolmogorov-Smirnov Test

\begin{tabular}{|c|c|c|}
\hline & & Kompetensi \\
\hline$N$ & & 105 \\
\hline \multirow[t]{2}{*}{ Normal Parameters ${ }^{a, b}$} & Mean & 32.5429 \\
\hline & Std. Deviation & 7.70992 \\
\hline \multirow[t]{3}{*}{ Most Extreme Differences } & Absolute & .100 \\
\hline & Positive & .073 \\
\hline & Negative & -.100 \\
\hline Kolmogorov-Smirnov Z & & 1.020 \\
\hline Asymp. Sig. (2-tailed) & & .249 \\
\hline
\end{tabular}

One-Sample Kolmogorov-Smirnov Test

\begin{tabular}{|c|c|c|}
\hline & & Kinerja \\
\hline$N$ & & 105 \\
\hline \multirow[t]{2}{*}{ Normal Parameters ${ }^{a, b}$} & Mean & 40.1429 \\
\hline & Std. Deviation & 6.68585 \\
\hline \multirow[t]{3}{*}{ Most Extreme Differences } & Absolute & .104 \\
\hline & Positive & .070 \\
\hline & Negative & -.104 \\
\hline Kolmogorov-Smirnov Z & & 1.061 \\
\hline Asymp. Sig. (2-tailed) & & .210 \\
\hline
\end{tabular}

One-Sample Kolmogorov-Smirnov Test

a. Test distribution is Normal.

\begin{tabular}{|ll|r|}
\hline \multicolumn{2}{|c|}{} & Motivasi \\
\hline $\mathrm{N}$ & & 105 \\
Normal Parameters & Mean & 28.8286 \\
Most Extreme Differences & Std. Deviation & 6.63971 \\
& Absolute & .119 \\
& Positive & .119 \\
Kolmogorov-Smirnov Z & Negative & -.091 \\
Asymp. Sig. (2-tailed) & & 1.218 \\
\end{tabular}

a. Test distribution is Normal.

b. Calculated from data.

\begin{tabular}{|l|l|c|c|c|c|}
\hline \multicolumn{1}{|c|}{ o. } & \multicolumn{1}{|c|}{ Variabel } & $\mathrm{n}$ & $\alpha$ & Asymp. Sig & Keterangan \\
\hline 1. & Kinerja & 105 & 0,05 & 0,210 & Normal \\
\hline 2. & Kompetensi & 105 & 0,05 & 0,249 & Normal \\
\hline 3 & Kompensasi & 105 & 0,05 & 0,128 & Normal \\
\hline 4 & Motivasi & 105 & 0,05 & 0,103 & Normal \\
\hline
\end{tabular}

\section{Kinerja (Y)}

Dari hasil perhitungan yang telah dilakukan dengan menggunakan bantuan komputer program SPSS 20, diperoleh nilai Asymp. Sig. (2-tailed) Asymp. Sig (2-tailed) = 0,210 lebih besar dari $\alpha=0,05$ dan $\mathrm{n}=105$. Dengan demikian dapat disimpulkan Y berdistribusi normal.

\section{Kompetensi $\left(\mathbf{X}_{1}\right)$}

Dari hasil perhitungan yang telah dilakukan dengan menggunakan bantuan komputer program SPSS 20, diperoleh nilai Asymp. Sig. (2-tailed) $=0,249$ lebih besar dari $\alpha=0,05$ dan $n=$ 105. Dengan demikian dapat disimpulkan sampel data variabel $X_{1}$ berasal dari populasi yang berdistribusi normal.

\section{Kompensasi $\left(\mathbf{X}_{2}\right)$}

Dari hasil perhitungan yang telah dilakukan dengan menggunakan bantuan komputer program SPSS 20, diperoleh nilai Asymp. Sig. (2-tailed) Asymp. Sig (2-tailed) = 0,128 lebih besar dari $\alpha=0,05$ dan $n=105$. Dengan demikian dapat disimpulkan $X_{2}$ berdistribusi normal.

\section{Motivasi $\left(\mathbf{X}_{3}\right)$}


Dari hasil perhitungan yang telah dilakukan dengan menggunakan bantuan komputer program SPSS 20, diperoleh nilai Asymp. Sig. (2-tailed) $=0,103$ lebih besar dari $\alpha=0,05$ dan $n=$ 105. Dengan demikian dapat disimpulkan sampel data variabel $\mathrm{X}_{3}$ berasal dari populasi yang berdistribusi normal.

\section{Uji Multikolinearitas}

Nilai VIF tidak melebihi 10 sehingga dapat disimpulkan bahwa model ini tidak terkena persoalan multikolinearitas.

Tabel 7. Uji Multikolineritas

\begin{tabular}{|ll|r|r|}
\hline \multirow{2}{*}{ Model } & \multicolumn{2}{|c|}{ Collinearity Statistics } \\
\cline { 3 - 4 } & & Tolerance & \multicolumn{1}{c|}{ VIF } \\
\hline 1 & (Constant) & & \\
& Kompetensi & .827 & 1.210 \\
& Kompensasi & .742 & 1.347 \\
& Motivasi & .757 & 1.321 \\
\hline
\end{tabular}

a. Dependent Variable: Kinerja

\begin{tabular}{|l|c|c|}
\hline \multicolumn{1}{|c|}{ Variabel } & Nilai Tolerance & Nilai VIF \\
\hline Kompetensi $\left(\mathrm{X}_{1}\right)$ & 0,827 & 1,210 \\
\hline Kompensasi $\left(\mathrm{X}_{2}\right)$ & 0,742 & 1,347 \\
\hline Motivasi $\left(\mathrm{X}_{3}\right)$ & 0,757 & 1,321 \\
\hline
\end{tabular}

\section{Uji Linieritas Regresi dan Signifikansi Regresi}

Uji linieritas adalah keadaan dimana hubungan antara variabel dependen dengan variabel independen bersifat linier (garis lurus) dalam range variabel independen tertentu. Uji ini dimaksudkan untuk melihat persamaan regresi pasangan variabel yang diteliti secara individual dengan asumsi bahwa jika secara individual semua pasangan memperlihatkan gejala-gejala pergerakan yang sama, maka hal itu juga akan terjadi jika dilakukan secara keseluruhan.

\section{Uji Linieritas regresi dan signifikansi regresi $Y$ atas $X_{1}$}

Tabel 8. Hasil Uji Signifikansi dan Linieritas $\mathrm{Y}$ atas $\mathrm{X}_{1}$

Persamaan Regresi $\hat{Y}=23,683+0,506 X 1$ 


\begin{tabular}{|c|c|c|c|c|c|c|}
\hline \multirow{2}{*}{\multicolumn{2}{|c|}{ Model }} & \multicolumn{2}{|c|}{ Unstandardized Coefficients } & \multirow{2}{*}{$\begin{array}{c}\text { Standardized } \\
\text { Coefficients } \\
\text { Beta }\end{array}$} & \multirow[b]{2}{*}{$\mathrm{t}$} & \multirow[b]{2}{*}{ Sig. } \\
\hline & & $\mathrm{B}$ & Std. Error & & & \\
\hline \multirow[t]{2}{*}{1} & (Constant) & 23.683 & 2.321 & & 10.206 & .000 \\
\hline & Kompetensi & .506 & .069 & .583 & 7.288 & .000 \\
\hline
\end{tabular}

a. Dependent Variable: Kinerja

\begin{tabular}{|c|c|c|c|c|c|c|}
\hline \multicolumn{7}{|c|}{ ANOVA ${ }^{a}$} \\
\hline \multicolumn{2}{|c|}{ Model } & $\begin{array}{l}\text { Sum of } \\
\text { Squares }\end{array}$ & df & Mean Square & $\mathrm{F}$ & Sig. \\
\hline \multirow[t]{3}{*}{1} & Regression & 1581.551 & 1 & 1581.551 & 53.108 & $.000^{6}$ \\
\hline & Residual & 3067.307 & 103 & 29.780 & & \\
\hline & Total & 4648.857 & 104 & & & \\
\hline
\end{tabular}

a. Dependent Variable: Kinerja

b. Predictors: (Constant), Kompetensi

Keterangan:

$* *$ Sangat signifikan $\left(F_{\text {hitung }}=53,108>F_{\text {tabel }} 0,99(1,103)=6,888\right)$

Berdasarkan hasil pengujian yang tersaji pada tabel di atas, dapat disimpulkan bahwa persamaan regresi $\hat{Y}=23,683+0,506 \mathrm{X} 1$ mempunyai $F_{\text {hitung }}=53,108>F_{\text {tabel }}=6,888$ pada $\alpha=$ 0,01 . Ini artinya persamaan regresi $\hat{Y}=23,683+0,506 \mathrm{X} 1$ tersebut adalah sangat signifikan dan linier. Dengan demikian, persamaan regresi tersebut menunjukkan bahwa untuk setiap kenaikan kinerja (Y) sebanyak satu skor, diharapkan terjadi kenaikan kompetensi (X1) rata-rata dengan skor 0,506. Lebih umum lagi bahwa kenaikan kompetensi sebesar 100\% diikuti oleh kenaikan kinerja karyawan sebesar $50,60 \%$.

\section{Uji Linieritas regresi dan signifikansi regresi $Y$ atas $X_{2}$}

Tabel 9. Hasil Uji Signifikansi dan Linieritas $\mathrm{Y}$ atas $\mathrm{X}_{2}$ Persamaan Regresi $\hat{Y}=19,407+0,614 X 2$

Coefficients $^{a}$

\begin{tabular}{|c|c|c|c|c|c|c|}
\hline \multirow{2}{*}{\multicolumn{2}{|c|}{ Model }} & \multicolumn{2}{|c|}{ Unstandardized Coefficients } & \multirow{2}{*}{$\begin{array}{c}\begin{array}{c}\text { Standardized } \\
\text { Coefficients }\end{array} \\
\text { Beta } \\
\end{array}$} & \multirow[b]{2}{*}{$\mathrm{t}$} & \multirow[b]{2}{*}{ Sig. } \\
\hline & & $\mathrm{B}$ & Std. Error & & & \\
\hline \multirow[t]{2}{*}{1} & (Constant) & 19.407 & 2.851 & & 6.808 & .000 \\
\hline & Kompensasi & .614 & .083 & .589 & 7.403 & .000 \\
\hline
\end{tabular}

a. Dependent Variable: Kinerja

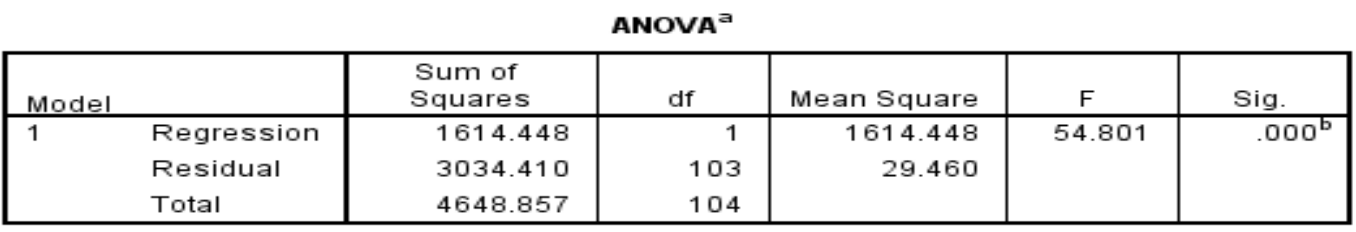

a. Dependent Variable: Kinerja

b. Predictors: (Constant), Kompensasi

Keterangan:

$* *$ sangat signifikan $\left(F_{\text {hitung }}=54,801>F_{\text {tabel } 0,99(1,107)}=6,888\right)$

Berdasarkan hasil pengujian yang tersaji pada tabel 4.13 di atas, dapat disimpulkan bahwa persamaan regresi $\hat{Y}=19,407+0,614 \mathrm{X} 2$ mempunyai $\mathrm{F}_{\text {hitung }}=54,801>\mathrm{F}_{\text {tabel }}=6,888$ pada $\alpha=$ 
0,01 . Ini artinya persamaan regresi $\hat{Y}=19,407+0,614 X 2$ tersebut adalah sangat signifikan dan linier. Dengan demikian, persamaan regresi tersebut menunjukkan bahwa untuk setiap kenaikan kinerja $(\mathrm{Y})$ sebanyak satu skor, diharapkan terjadi kenaikan motivasi $\left(\mathrm{X}_{2}\right)$ rata-rata dengan skor 0,614. Lebih umum lagi bahwa kenaikan kompensasi sebesar 100\% diikuti oleh kenaikan kinerja karyawan sebesar $61,40 \%$.

\section{Uji Linieritas regresi dan signifikansi regresi $Y$ atas $X_{3}$}

Tabel 9. Hasil Uji Signifikansi dan Linieritas $\mathrm{Y}$ atas $\mathrm{X}_{2}$

Persamaan Regresi $\hat{Y}=21,716+0,639 \mathrm{X} 2$

Coefficients $^{a}$

\begin{tabular}{|c|c|c|c|c|c|c|}
\hline \multirow{2}{*}{\multicolumn{2}{|c|}{ Model }} & \multicolumn{2}{|c|}{ Unstandardized Coefficients } & \multirow{2}{*}{$\begin{array}{c}\text { Standardized } \\
\text { Coefficients } \\
\text { Beta }\end{array}$} & \multirow[b]{2}{*}{$\mathrm{t}$} & \multirow[b]{2}{*}{ Sig. } \\
\hline & & $\mathrm{B}$ & Std. Error & & & \\
\hline \multirow[t]{2}{*}{1} & (Constant) & 21.716 & 2.267 & & 9.577 & .000 \\
\hline & Motivasi Kerja & .639 & .077 & .635 & 8.337 & .000 \\
\hline
\end{tabular}

a. Dependent Variable: Kinerja

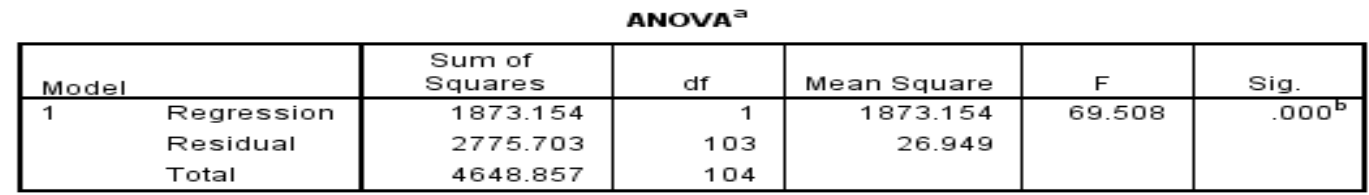

a. Dependent Variable: Kinerja

b. Predictors: (Constant), Motivasi Kerja

Keterangan:

$* *_{\text {sangat signifikan }\left(F_{\text {hitung }}=69,508>F_{\text {tabel } 0,99(1,78)}=6,888\right)}$

Berdasarkan hasil pengujian yang tersaji pada tabel 4.14 di atas, dapat disimpulkan bahwa persamaan regresi $\hat{Y}=21,716+0,639 X 2$ mempunyai $F_{\text {hitung }}=69,508>F_{\text {tabel }}=6,888$ pada $\alpha=$ 0,01 . Ini artinya persamaan regresi $\hat{Y}=21,716+0,639 X 3$ tersebut adalah sangat signifikan dan linier. Dengan demikian, persamaan regresi tersebut menunjukkan bahwa untuk setiap kenaikan kinerja (Y) sebanyak satu skor, diharapkan terjadi kenaikan motivasi $\left(\mathrm{X}_{3}\right)$ rata-rata dengan skor 0,639. Lebih umum lagi bahwa kenaikan motivasi sebesar 100\% diikuti oleh kenaikan kinerja karyawan sebesar $63,90 \%$.

\section{Uji Linieritas Regresi dan Signifikansi Regresi $X_{3}$ atas $X_{1}$}

Tabel 10. Hasil ANAVA Uji Signifikansi dan Linieritas $X 3$ atas $X_{1}$ Persamaan Regresi:

$$
\mathrm{X}_{3}=19,233+0,295 \mathrm{X}_{1}
$$

\begin{tabular}{|c|c|c|c|c|c|c|}
\hline \multicolumn{7}{|c|}{ Coefficients $^{a}$} \\
\hline \multirow{2}{*}{\multicolumn{2}{|c|}{ Model }} & \multicolumn{2}{|c|}{ Unstandardized Coefficients } & \multirow{2}{*}{$\begin{array}{c}\text { Standardized } \\
\text { Coefficients } \\
\text { Beta }\end{array}$} & \multirow[b]{2}{*}{$\mathrm{t}$} & \multirow[b]{2}{*}{ Sig. } \\
\hline & & $\mathrm{B}$ & Std. Error & & & \\
\hline & (Constant) & 19.233 & 2.666 & & 7.215 & .000 \\
\hline & Kompetensi & .295 & .080 & .342 & 3.698 & .000 \\
\hline
\end{tabular}

a. Dependent Variable: Motivasi Kerja 


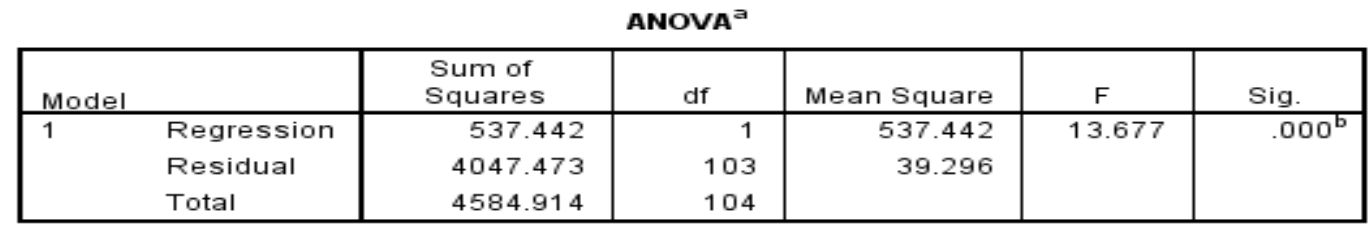

a. Dependent Variable: Motivasi Kerja

b. Predictors: (Constant), Kompetensi

Keterangan:

Sangat signifikan ( $\left.F_{\text {hitung }} 13,677>F_{\text {tabel0,99(1,103) }}=6,888\right)$

Berdasarkan hasil pengujian yang tersaji pada tabel 4.15 di atas, dapat disimpulkan bahwa persamaan regresi $X_{3}=19,233+0,295 X_{1}$ mempunyai $F_{\text {hitung }}=13,677>F_{\text {tabel }}=6,888$ pada $\alpha(0,01)$. Ini artinya persamaan regresi $X_{3}=19,233+0,295 X_{1}$ tersebut adalah signifikan dan linier. Ini menunjukkan bahwa setiap kenaikan kompetensi $\left(\mathrm{X}_{1}\right)$ sebanyak satu satuan, diharapkan terjadi kenaikan motivasi (X3) dengan skor rata-rata 0,295. Lebih umum lagi bahwa kenaikan kualitas kompetensi sebesar 100\% diikuti oleh kenaikan motivasi sebesar 29,50\%. Dengan kata lain setiap peningkatan satu skor variabel $X_{1}$ mengakibatkan peningkatan variabel $\mathrm{X} 3$ sebesar 0,295 pada konstanta 19,233.

\section{Uji Linieritas Regresi dan Signifikansi Regresi $X_{3}$ atas $X_{2}$}

Tabel 11. Hasil ANAVA Uji Signifikansi dan Linieritas $\mathrm{X} 3$ atas $\mathrm{X}_{2}$ Persamaan

Regresi: $\mathrm{X}_{3}=12,916+0,424 \mathrm{X}_{2}$

coefficients ${ }^{a}$

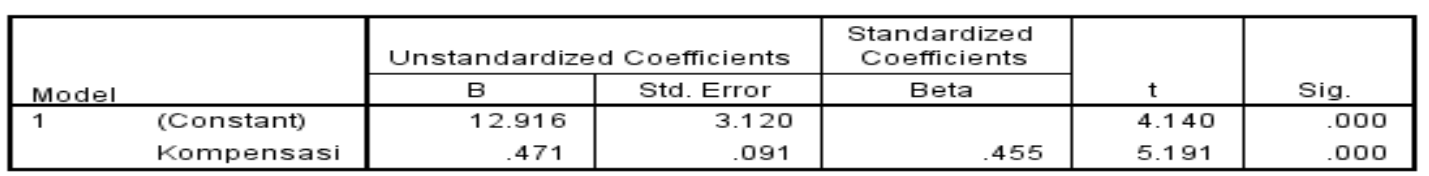

a. Dependent Variable: Motivasi Kerja

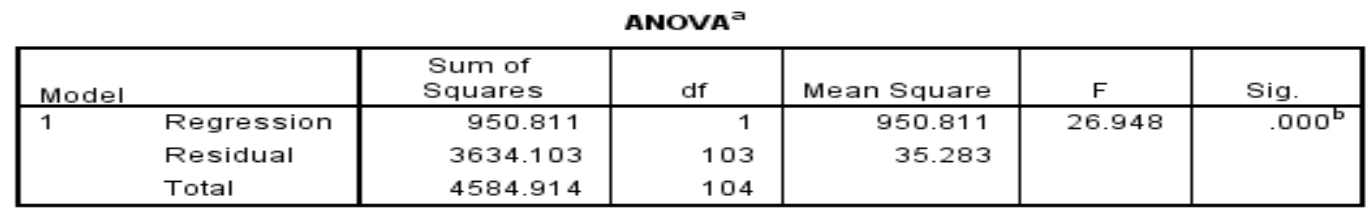

a. Dependent Variable: Motivasi Kerja

b. Predictors: (Constant), Kompensasi

Keterangan:

Sangat signifikan ( $F_{\text {hitung }} 26,948>F_{\text {tabel0,99(1,75) }}=6,888$ )

Berdasarkan hasil pengujian yang tersaji pada tabel 4.16 di atas, dapat disimpulkan bahwa persamaan regresi $\mathrm{X}_{3}=12,916+0,424 \mathrm{X}_{2}$ mempunyai $\mathrm{F}_{\text {hitung }}=26,948>\mathrm{F}_{\text {tabel }}=6,888$ pada $\alpha$ $(0,01)$. Ini artinya persamaan regresi $X_{3}=12,916+0,424 X_{2}$ tersebut adalah signifikan dan linier. Dengan demikian persamaan regresi tersebut menunjukkan bahwa untuk setiap kenaikan kompensasi $\left(\mathrm{X}_{2}\right)$ sebanyak satu satuan, diharapkan terjadi kenaikan motivasi (X3) dengan skor rata-rata 0,424. Lebih umum lagi bahwa kenaikan kualitas kompensasi sebesar 100\% mengakibatkan kenaikan motivasi sebesar 47,10\%. Dengan kata lain bahwa setiap peningkatan satu skor variabel $\mathrm{X}_{2}$ mengakibatkan peningkatan variabel $\mathrm{X}_{3}$ sebesar 0,424 pada konstanta 12,916. 
Tabel 12. Rangkuman Uji Linearitas dan Signifikansi Koefisien Regresi

\begin{tabular}{|l|c|c|c|}
\hline \multirow{2}{*}{ Variabel } & \multicolumn{2}{|c|}{$\alpha=0,01$} & \multirow{2}{*}{ Kesimpulan } \\
\cline { 2 - 4 } & $\mathrm{F}_{\text {hitung }}$ & $\mathrm{F}_{\text {tabel }}$ & \\
\hline $\begin{array}{l}\mathrm{X}_{1} \rightarrow \mathrm{Y} \\
\mathrm{Y}=19,994+0,499 \mathrm{X} 1\end{array}$ & 68,736 & 6,888 & $\begin{array}{l}\text { Linear dan } \\
\text { Signifikan }\end{array}$ \\
\hline $\begin{array}{l}\mathrm{X}_{2} \rightarrow \mathrm{Y} \\
\hat{\mathrm{Y}}=11,345+0,590 \mathrm{X} 2\end{array}$ & 64,941 & 6,888 & $\begin{array}{c}\text { Linear dan } \\
\text { Signifikan }\end{array}$ \\
\hline $\begin{array}{l}\mathrm{X}_{3} \rightarrow \mathrm{Y} \\
\hat{Y}=12,885+0,629 \mathrm{X} 3\end{array}$ & 89,916 & 6,888 & $\begin{array}{l}\text { Linear dan } \\
\text { Signifikan }\end{array}$ \\
\hline $\begin{array}{l}\mathrm{X}_{1} \rightarrow \mathrm{X}_{3} \\
\mathrm{X}_{3}=19,233+0,295 \mathrm{X}_{1}\end{array}$ & 13,677 & 6,888 & $\begin{array}{l}\text { Linear dan } \\
\text { Signifikan }\end{array}$ \\
\hline $\begin{array}{l}\mathrm{X}_{2} \rightarrow \mathrm{X}_{3} \\
\mathrm{X}_{3}=12,916+0,424 \mathrm{X}_{2}\end{array}$ & 26,948 & 6,888 & $\begin{array}{l}\text { Linear dan } \\
\text { Signifikan }\end{array}$ \\
\hline
\end{tabular}

\section{PEMBAHASAN}

\section{Pengaruh Langsung Positif Kompetensi Terhadap Kinerja}

Hasil penelitian empirik menemukan bahwa kompetensi berpengaruh langsung positif terhadap kinerja, dinyatakan bahwa besarnya kontribusi kompetensi terhadap kinerja sebesar $11,97 \%(0,346 \times 0,346 \times 100 \%)$. Ini menunjukkan bahwa $11,97 \%$ dalam kinerja dapat dijelaskan oleh kompetensi, sedangkan sisanya 88,03\% dipengaruhi faktor lain di luar model.

Pada hasil uji koefisien menunjukkan bahwa kompetensi berpengaruh langsung positif terhadap kinerja terjadi secara signifikan. Hal ini dapat dilihat dari uji signifikansi koefisien korelasi parsial (uji t) diperoleh nilai harga thitung $=5,101$ dan harga tabel $=2,639$ pada tingkat signifikansi 0,01. Fakta ini mengungkapkan bahwa $\mathrm{t}_{\text {hitung }}>\mathrm{t}_{\text {tabel }}$ berarti $\mathrm{H}_{0}$ ditolak dan $\mathrm{H}_{1}$ diterima. Artinya kompetensi berpengaruh positif dan signifikan terhadap kinerja. Hasil penelitian ini didukung oleh Spencer dan Spencer (dalam Dharmanegara, Sitiari, dan Wirayudha, 2016: 21) bahwa kompetensi sebagai karakteristik yang mendasari seorang individu yang secara kausal terkait dengan kinerja yang unggul dalam suatu pekerjaan. Disamping itu, kompetensi akan mendorong karyawan untuk mendapatkan dan menerapkan kemampuan dan pengetahuan sesuai kebutuhan pekerjaan, karena hal ini merupakan instrumen bagi pencapaian target.

Hal ini mengindikasikan bahwa kompetensi sebagai karakteristik mendasar yang dapat menghasilkan kinerja unggul dan atau efektif dalam suatu pekerjaan. Kinerja karyawan diciptakan karena kemampuan kerja karyawan yang dimanifestasikan dalam bekerja adalah sangat baik. Kompetensi diciptakan berhubungan dengan bakat, sifat personalitas dan pengetahuan yang telah dicapai seseorang. Pernyataan tersebut didukung oleh Sanda, Sackey dan Fältholm (2011:11) bahwa kompetensi merupakan karakteristik yang menghasilkan kinerja yang efektif dan luar biasa.

Berkaitan dengan hal tersebut bahwa kinerja yang meningkat senantiasa didambakan oleh setiap organisasi, karena kinerja adalah hasil kerja yang dapat dicapai oleh seseorang atau sekelompok orang dalam suatu organisasi sesuai dengan wewenang dan tanggung jawab masingmasing, dalam rangka upaya mencapai tujuan organisasi. Senada dengan pendapat dari Masruhi (2010: 23) bahwa kompetensi SDM yang dimiliki karyawan mampu menciptakan dan membentuk kinerja karyawan, karena kinerja karyawan yang baik akan berdampak besar bagi kinerja organisasi. Dari pembahasan tersebut jelaslah bahwa kompetensi berpengaruh langsung positif terhadap kinerja. 


\section{Pengaruh Langsung Positif Kompensasi terhadap Kinerja}

Hasil penelitian empirik menemukan bahwa kompensasi berpengaruh langsung positif terhadap kinerja, dinyatakan bahwa besarnya kontribusi kompensasi terhadap kinerja menunjukkan arah yang positif yaitu sebesar 0,287. Ini menunjukkan bahwa 8,24\% (0,287 x 0,287 x 100\%) dalam kinerja dapat dijelaskan oleh kompensasi, sedangkan sisanya 91,76\% dipengaruhi faktor lain di luar model.

Pada hasil uji koefisien menunjukkan bahwa kompensasi berpengaruh langsung positif terhadap kinerja terjadi secara signifikan. Hal ini dapat dilihat dari uji signifikansi koefisien korelasi parsial (uji $\mathrm{t}$ ) diperoleh nilai harga $\mathrm{t}_{\mathrm{hitung}}=4,005$ dan harga $\mathrm{t}_{\text {tabel }}=2,639$ pada tingkat signifikansi 0,01. Fakta ini mengungkapkan bahwa $\mathrm{t}_{\text {hitung }}>\mathrm{t}_{\text {tabel }}$ berarti $\mathrm{H}_{0}$ ditolak dan $\mathrm{H}_{1}$ diterima. Artinya kompensasi berpengaruh positif dan signifikan terhadap kinerja.

Hasil penelitian ini didukung oleh pendapat Qureshi dan Sajjad (2015:172) bahwa kompensasi dan ketentuan yang diberikan kepada karyawan dapat mempengaruhi moral dan kinerjanya dengan cara apapun. Pendapat ini mengungkapkan bahwa karyawan dengan kompensasi tinggi biasanya menunjukkan kinerja yang luar biasa dalam bidang produktivitas dan promosi praktik etika di tempat bekerja yang bersangkutan. Upaya ini dilakukan karena karyawan mempunyai sifat kompleksitas dalam suasana dan kondisi bagaimanapun dalam menjalankan pekerjaannya. Karyawan selalu dilandasi oleh keinginan untuk mencapai tujuan tertentu.

Menurut Handoko (2018:115) bahwa keterkaitan kompensasi dengan kinerja karyawan sangatlah signifikan. Semakin tinggi kompensasi semakin tinggi tingkat kinerja para karyawan. Dengan perkataan lain bahwa derajat kepuasan yang semakin tinggi akan semakin meningkatkan motivasi karyawan dalam meraih kinerja yang tinggi. Jika dikelola dengan baik, kompensasi membantu perusahaan untuk mencapai tujuan dalam memperoleh, memelihara, dan menjaga karyawan dengan optimum.

Disamping itu, karyawan merupakan aset organisasi yang perlu dipelihara keutuhannya, karena karyawan merupakan tenaga kerja yang memiliki pikiran, kebutuhan dan harapan-harapan tertentu. Tenaga kerja dengan segala kebutuhan sangat memerlukan kompensasi yang adil dan layak, karena faktor-faktor tersebut akan mempengaruhi kinerja karyawan serta kecintaan terhadap organisasi. Hal ini senada dengan pendapat dari Wekesa dan Nyaroo (2013:1-4) bahwa pemberian kompensasi dapat diakui sebagai faktor utama dalam mempengaruhi kinerja karyawan.

Dengan demikian kompensasi yang diberikan kepada karyawan dan relevansinya terhadap kinerja sangatlah penting. Hal ini dikarenakan bahwa kompensasi sering dianggap sebagai imbalan keuangan dan non-keuangan langsung dan tidak langsung yang diberikan kepada karyawan atas dasar nilai pekerjaan, kontribusi pribadi mereka, dan kinerja mereka. Dengan demikian jelaslah bahwa kompensasi berpengaruh langsung positif terhadap kinerja.

\section{Pengaruh Langsung Positif Motivasi terhadap Kinerja}

Hasil penelitian empirik menemukan bahwa motivasi berpengaruh langsung positif terhadap kinerja, dinyatakan bahwa besarnya kontribusi motivasi terhadap kinerja menunjukkan arah yang positif yaitu sebesar 0,386 . Ini menunjukkan bahwa $14,90 \%(0,386 \times 0,386 \times 100 \%)$ dalam kinerja dapat dijelaskan oleh motivasi, sedangkan sisanya $85,10 \%$ dipengaruhi faktor lain 
di luar model. Hasil penelitian in didukung oleh pendapat Zameer et al (2014: 297) bahwa motivasi memiliki pengaruh yang kuat terhadap kinerja karyawan.

Motivasi dalam kaitannya sebagai pembinaan karyawan untuk mencapai kinerja yang tinggi dan juga sebagai kebijakan perusahaan dalam pengambilan keputusan sehingga arah dan tujuan perusahaan menjadi jelas dan terarah. Hal ini senada dari pendapat Hala (2009) dalam (Bett, Onyango dan Bantu, 2013: 549) bahwa tingkat kinerja tergantung pada tingkat motivasi yang merangsang seseorang untuk bekerja dan melaksanakan tugas-tugas yang diperlukan dalam mencapai tujuan.

Motivasi dapat diidentifikasikan ke dalam faktor-faktor pemuas dan penguat sebagai unsur yang mempengaruhi harapan dari karyawannya, dengan perkataan lain, motivasi dapat menentukan dan mengetahui arah kebijakan organisasi dalam menetapkan produktivitasnya, dan dapat menyebabkan seseorang melakukan perbuatan yang bermanfaat dalam mencapai tujuan tertentu. Motivasi penting dilakukan secara berkelanjutan dan berkesinambungan dengan harapan agar hasil motivasi ini dapat dijadikan pedoman bagi organisasi untuk dapat meningkatkan kinerjanya.

Motivasi yang ditimbulkan oleh perusahaan atau berasal dalam diri karyawan akan meningkatkan kinerja yang lebih tinggi. Hal ini dikarenakan ketika mereka merasa bahwa perusahaan yang peduli terhadap kesejahteraan mereka, mereka terlibat dalam proses manajemen, dan lingkungan kerja bersifat positif. Sementara keterlibatan pengendalian motivasi akan menciptakan lingkungan yang lebih produktif, apabila para karyawan merasa diperlakukan secara adil dan hormat, sikap ini akan mengembangkan dan membimbing perilaku mereka ke arah yang positif, sehingga mereka bersemangat dan tertarik pada pekerjaan mereka yang berdampak pada produktivitas kerja mereka.

Dari pembahasan tersebut jelaslah motivasi berpengaruh terhadap kinerja. Motivasi sebagai faktor potensial pada individu yang dikembangkan dengan persepsi kerja, motif kerja dan pencapaian untuk menghasilkan kinerja yang tinggi. Dengan demikian jelaslah bahwa motivasi berpengaruh langsung positif dan signifikan terhadap kinerja.

\section{Pengaruh Langsung Positif Kompetensi Terhadap Motivasi}

Hasil penelitian empirik menemukan bahwa kompetensi berpengaruh langsung positif terhadap motivasi, dinyatakan bahwa besarnya kontribusi motivasi terhadap kinerja menunjukkan arah yang positif yaitu sebesar 0,203. Ini menunjukkan bahwa $4,12 \%(0,203 \times 0,203 \times 100 \%)$ dalam motivasi dapat dijelaskan oleh kompetensi, sedangkan sisanya 95,88\% dipengaruhi faktor lain di luar model.

Temuan ini diperkuat dengan pendapat Carrel (2005:9) bahwa pentingnya pemberian penghargaan dan pengakuan pegawai sesuai dengan prestasinya. Dengan pemberian penghargaan dan pengakuan dari organisasi diharapkan dapat memacu pegawai dan termotivasi dalam memanfaatkan kemampuannya untuk melakukan pekerjaan dan meningkatkan upaya kerja sehingga pada gilirannya dapat meningkatkan pula karier di dalam dunia kerjanya. Kompetensi seseorang dapat ditunjukan dengan hasil kerja atau karya, pengetahuan, ketrampilan, perilaku, karakter, sikap, motivasi dan bakatnya.

Motivasi dapat diartikan sebagai suatu sikap yang harus dimiliki oleh setiap karyawan untuk menunjukkan loyalitas terhadap organisasi di mana mereka bekerja. Pada dasarnya motivasi 
kerja berkaitan erat dengan aspek-aspek psikologis dalam penerimaan dan kepercayaan terhadap nilai-nilai serta tujuan organisasi dimunculkan melalui keinginan untuk mempertahankan keanggotaan dalam organisasi. Untuk menanamkan loyalitas karyawan supaya motivasi kerja tinggi, hendaknya sejak awal memasuki lingkungan organisasi baru, karyawan diperkenalkan dengan visi, misi, tujuan, sasaran nilai, serta motivasi kerja tersebut. Dengan demikian jelaslah bahwa kompetensi berpengaruh langsung positif terhadap motivasi kerja.

\section{Pengaruh Langsung Positif Kompensasi terhadap Motivasi kerja}

Hasil penelitian empirik menemukan bahwa kompensasi berpengaruh langsung positif terhadap motivasi kerja, dinyatakan bahwa besarnya kontribusi kompensasi terhadap motivasi kerja menunjukkan arah yang positif yaitu sebesar 0,381. Ini menunjukkan bahwa $14,52 \%(0,381$ x $0,381 \times 100 \%$ ) dalam motivasi kerja dapat dijelaskan oleh kompensasi, sedangkan sisanya $85,48 \%$ dipengaruhi faktor lain di luar model.

Temuan ini sejalan Penelitian yang dilakukan oleh Adeoye \& Elegunde, 2014 bahwa kompensasi dan manajemen motivasi harus sangat mendasar bagi organisasi dalam memfasilitasi pencapaian tujuan. Agar organisasi memiliki keunggulan kompetitif, penghargaan yang bermanfaat dan strategi motivasi harus menjadi pertimbangan utama dalam perekrutan, retensi, dan peningkatan keterampilan karyawan yang mendedikasikan diri pada pencapaian organisasi.

Bratton \& Gold (2017) dalam Susanto, Haryono dan Sardiyo (2020:2441) berpendapat bahwa organisasi yang melakukan kompensasi pembayaran jasa adalah untuk meningkatkan kinerja karyawan; ini karena sistem pemberian ini akan memotivasi karyawan untuk meningkatkan kinerja mereka.

Peningkatan kompensasi bisa mewujudkan motivasi karyawan jika dapat mencakup berbagai jenis penghargaan dan tunjangan seperti gaji, pembayaran insentif, serta tunjangan dan layanan lainnya. Namun, apabila seorang karyawan mendapatkan kompensasi yang rendah, karyawan akan bekerja lebih lambat dan tidak hadir. Kompensasi yang diberikan perusahaan salah satunya adalah tingkat kesejahteraan yang dimaksud, apabila kebutuhan tersebut telah terpenuhi, mereka dapat hidup layak, dengan kelayakan hidup ini mereka akan lebih tenang dalam melaksanakan tugas-tugasnya, dan dengan ketenangan tersebut diharapkan mereka akan lebih berkompensasi. Senada dengan pendapat dari Maslow (2004 : 154) bahwa kebutuhan manusia dapat disusun dalam bentuk hirarki. Tiap kebutuhan tidak akan timbul apabila, kebutuhan yang lebih rendah tingkatnya belum terpenuhi. Hirarki kebutuhan manusia menurut maslow adalah: psikologis, rasa aman, social ego, dan perwujudan diri. Kompensasi dapat mengikat karyawan supaya tidak keluar dari perusahaan belum tentu dapat menimbulkan semangat dan kegairahan kerja karyawan. Dengan diberikannya kompensasi, maka akan dapat meningkatkan motivasi kerja karyawan dan akan menjadi karyawan betah kerja di perusahaan.

Hal ini sudah menjadi keharusan karena tujuan dari setiap organisasi adalah untuk meningkatkan motivasi kerja karyawan yang akan mengakibatkan produktivitas yang lebih tinggi dan profitabilitas. Sebaliknya, apabila motivasi kerja karyawan tersebut tidak terpenuhi, mereka kurang dapat hidup dengan layak, sehingga mereka menjadi kurang tenang dalam melaksanakan tugas-tugasnya, yang pada akhirnya akan mengurangi kecintaannya terhadap pekerjaannya dan 
pada gilirannya akan terjadi pelanggaran-pelanggaran peraturan. Dengan demikian jelaslah bahwa kompensasi berpengaruh langsung positif terhadap motivasi kerja.

\section{KESIMPULAN}

1. Terdapat pengaruh langsung positif kompetensi terhadap kinerja. Ini menunjukan bahwa perbaikan kompetensi akan mengakibatkan peningkatan kinerja. Dinyatakan bahwa besarnya kontribusi kompetensi terhadap kinerja sebesar $11,97 \%(0,346$ x 0,346 x 100\%). Ini menunjukkan bahwa 11,97\% dalam kinerja dapat dijelaskan oleh kompetensi, sedangkan sisanya $88,03 \%$ dipengaruhi faktor lain di luar model

2. Terdapat pengaruh langsung positif kompensasi terhadap kinerja. Ini menunjukan bahwa perbaikan kompensasi akan mengakibatkan peningkatan perubahan kinerja.Dinyatakan bahwa besarnya kontribusi kompensasi terhadap kinerja menunjukkan arah yang positif yaitu sebesar 0,287. Ini menunjukkan bahwa 8,24\% (0,287 x 0,287 x 100\%) dalam kinerja dapat dijelaskan oleh kompensasi, sedangkan sisanya 91,76\% dipengaruhi faktor lain di luar model.

3. Terdapat pengaruh langsung positif motivasi kerja terhadap kinerja. Ini menunjukan bahwa perbaikan motivasi akan mengakibatkan peningkatan kinerja. Dinyatakan bahwa besarnya kontribusi motivasi terhadap kinerja menunjukkan arah yang positif yaitu sebesar 0,386 . Ini menunjukkan bahwa 14,90\% (0,386 x 0,386 x 100\%) dalam kinerja dapat dijelaskan oleh motivasi, sedangkan sisanya 85,10\% dipengaruhi faktor lain di luar model.

4. Terdapat pengaruh langsung positif kompetensi terhadap motivasi. Ini menunjukan bahwa perbaikan kompetensi akan mengakibatkan peningkatan motivasi. Dinyatakan bahwa besarnya kontribusi motivasi terhadap kinerja menunjukkan arah yang positif yaitu sebesar 0,203 . Ini menunjukkan bahwa 4,12\% (0,203 x 0,203 x 100\%) dalam motivasi dapat dijelaskan oleh kompetensi, sedangkan sisanya 95,88\% dipengaruhi faktor lain di luar model.

5. Terdapat pengaruh langsung positif kompensasi terhadap motivasi. Ini menunjukan bahwa perbaikan kompensasi akan mengakibatkan peningkatan motivasi. Dinyatakan bahwa besarnya kontribusi kompensasi terhadap motivasi kerja menunjukkan arah yang positif yaitu sebesar 0,381. Ini menunjukkan bahwa 14,52\% (0,381 x 0,381 x 100\%) dalam motivasi kerja dapat dijelaskan oleh kompensasi, sedangkan sisanya 85,48\% dipengaruhi faktor lain di luar model.

\section{DAFTAR PUSTAKA}

Adeoye, A. O., \& Elegunde, A. F. (2014). Compensation management and motivation: Cooking utensils for organisational performance. Mediterranean Journal of Social Sciences, $5(27$ P1), 88.

Ardana I Komang, Mujiati Ni Wayan, Utama I Wayan Mudiartha. 2012. Manajemen Sumber Daya Manusia. Yogyakarta: Graha Ilmu.

Aries, Susanty, dan Sigit, Wahyu, Baskoro. (2012). Pengaruh Motivasi Kerja dan Gaya Kepemimpinan terhadap Disiplin Kerja Serta Dampaknya pada Kinerja Karyawan (Studi Kasus pada PT. Pln (Persero) Apd Semarang). JATI Undip, Vol VII, No 2, Mei 2012.

Bett, Wesley Kipsang; Onyango, Maria; Bantu, Edward. 2013. Role of Teacher Motivation on Student's Performance at Secondary School Level in Kenya (A Case Study of Kericho District). International Journal of Advance Research Vol. 1 Issue 6 pp: 547-553 
Carrel, M.R. \& Dittrich, J.E. 2005. Equity theory: the recent literature, methodological considerations, and new directions. Academy of Management Review, 202-208.

Dessler, Gary. 2015. Manajemen Sumber Daya Manusia. Jakarta: Indeks.

Dharmanegara, I. B. A., Sitiari, N. W., \& Wirayudha, I. D. G. N. 2016. Job competency and work environment: The effect on job satisfaction and job performance among SME's worker. IOSR Journal of Business and Management, 18(1), 19-26.

Ghozali, Imam. 2016. Aplikasi Analisis Multivariate dengan Program IBM SPSS 23. Edisi 8. Semarang: Badan Penerbit Universitas Diponegoro.

Kandula R. Srinivas. 2013. Competency Based Human Resource Management, Delhi: Gate Corporation.

Mangkunegara, Anwar Prabu. 2010. Evaluasi Kinerja SDM. Bandung: Refika Aditama.

Mondy, R. Wayne, and Robert M. Noe. 2010. Human Resource Management. Elevenh Edition. USA: Prentice Hall.

Nawawi, H. Hadari. 2011. Manajemen Sumber Daya Manusia untuk bisnis yang kompetitif. Yogyakarta: Gadjah Mada University Press.

Qureshi, M. O., \& Sajjad, S. R. 2015. An Empirical Analysis of the Impact of Compensation on Job Performance and Work-Family Conflict in the Kingdom of Saudi Arabia a Correlation Model. European Scientific Journal February 2015 edition, 11(4), 170-187.

Rachmawati, Ike Kusdyah. 2011. Manajemen Sumber Daya Manusia. Yogyakarta: ANDI.

Rivai Veithzal, Sagala Ella Jauvani. 2011. Manajemen Sumber Daya Manusia untuk Perusahaan dari Teori ke Praktik. Jakarta: Raja Grafindo Persada.

Safuan, Ismartaya. 2019. Manajemen Sumber Daya Manusia. Bandung: CV. Alfabeta.

Safuan, S., Putranto, U., \& Aryanda, A. (2018). Faktor - Faktor yang Mempengaruhi Kinerja Pegawai Balai Besar Karantina Pertanian Tanjung Priok Jakarta. Jesya (Jurnal Ekonomi Dan Ekonomi Syariah), 2(1), 1-8. https://doi.org/https://doi.org/10.36778/jesya.v2i1.28

Safuan, Safuan. "Manajemen Sumberdaya Karyawan Unit USAha PT Pelabuhan Indonesia II (Studi Kasus Human Resource Management Kso Terminal Petikemas Koja)." Seminar Nasional Sains dan Teknologi Universitas Muhammadiyah Jakarta 2016, Jakarta, Indonesia, 2016. University of Muhammadiyah Jakarta, 2016.

Sanda, M. A., Sackey, J., \& Fältholm, Y. 2011. Managerial competence and non-performance of small firms in a developing economy. International Journal of Contemporary Business Studies, 2(3), 6-24.

Santoso, Singgih. 2010. Statistik Parametrik: konsep dan aplikasi dengan SPSS. Jakarta: PT. Elex Media Komputindo.

Sedarmayanti. 2011. Manajemen Sumber Daya Manusia Reformasi Birokrasi dan Manajemen Pegawai Negri Sipil. Bandung: Refika Aditama.

Sudarmanto,R. Gunawan.2013.Statistik Terapan Berbasis Komputer Dengan Program IBM SPSS Statistics 19.Jakarta:PT Mitra Wacana Media.

Sugiyono. (2017). Metode Penelitian Kuantitatif, Kualitatif, dan R\&D. Bandung: CV. Alfabeta.

Sunyoto, Danang. 2012. Manajemen Sumber Daya Manusia. Yogyakarta: CAPS

Susanto, Y., \& Siswoyo Haryono, S. (2020). The Effect of Leadership and Compensation on Employee Performance: Evaluating the Role of Work Motivation. Journal of Talent Development and Excellence, 12(2s), 2439-2449. 
Sutrisno, Edy. 2010. Manajemen Sumber Daya Manusia, Jakarta: Prenadamedia Group.

Torang, S. 2013. Organisasi \& Manajemen; Perilaku, Struktur, Budaya \& Perubahan Organisasi. Bandung: Penerbit Alfabeta.

Umi Narimawati, Sri Dewi Anggadini dan Linna Ismawati. 2010. Penilisan Karya Ilmiah. Bekasi: Genesis.

Wekesa, J. N., \& Nyaroo, S. (2013). Effect of compensation on performance of public secondary school teachers in Eldoret Municipality Kenya. International Journal of Scientific and Research Publications, 3(6), 1-4.

Wibowo. 2011. Manajemen Kinerja. Jakarta: RajaGrafindo Persada.

Zameer, H., Ali, S., Nisar, W., \& Amir, M. (2014). The impact of the motivation on the employee's performance in beverage industry of Pakistan. International journal of academic research in accounting, finance and management sciences, 4(1), 293-298. 